\title{
THE DYNAMIC ASSOCIATION BETWEEN CEO-DUALITY AND BANK PERFORMANCE: THE MODERATING ROLE OF BOARD SIZE
}

\author{
DOI: 10.17261/Pressacademia.2017.754 \\ RJBM-V.4-ISS.4-2017(3)-p.460-468 \\ Ozcan Isik ${ }^{1}$ \\ ${ }^{1}$ Cumhuriyet University, Department of Banking and Finance, Sivas, Turkey. ozcan@live.com
}

\section{To cite this document}

Isik, O. (2017). The dynamic association between CEO duality and bank performance: the moderating role of board size. Research Journal of Business and Management (RJBM), V.4, Iss.4, p.460-468.

Permemant link to this document: http://doi.org/10.17261/Pressacademia.2017.754

Copyright: Published by PressAcademia and limited licenced re-use rights only.

\section{ABSTRACT}

Purpose - The aim of this study is to examine the association between CEO-duality and bank financial performance in Turkey.

Methodology - All parameter estimates of regression models are based on the system GMM panel regression analyses. Our data covers all commercial banks operating in Turkish banking sector during the period 2007-2013.

Findings - Our empirical results imply that CEO-duality has a significantly positive effect on bank financial performance measured by the ratio of net income to the average total assets. In addition, we find a negative moderating impact of board on the positive linkage between CEO-duality and bank performance.

Conclusion - It can be concluded that as the number of members of the board raises, the positive influence of CEO-duality decreases for Turkish banking sector in the analyzed period.

Keywords: CEO-duality, board size, corporate governance, commercial banks, Turkey.

JEL Codes: C33, G21, G34

\section{INTRODUCTION}

In recent years, especially since the 2000 's, corporate governance issues have come to the fore due to the scandals regarding firms in the countries such as the USA, Italy, Holland and China and financial crises. All these problems have caused the shareholders of the firms to suffer serious losses.

The board of directors is the most important corporate governance mechanism between the firm's shareholders and those who manage the firm. At the same time, the board of directors primarily monitors financial performance of the firm and counsels firm's management, with the aim of protecting interests of shareholders. The most important role of the board of directors and its chairman is to hire, monitor, discipline, compensate, and fire the chief executive officer (CEO). It is also expected the CEO to manage the firm in line with the interests of shareholders of the firm and to inform the board of directors concerning the firm's activities (Fama and Jensen, 1983; Donaldson and Davis, 1991; Montgomery and Kaufman, 2003; Nahar Abdullah, 2004; Strebel, 2004; Nicholson and Kiel, 2007; Elsayed, 2010).

How the leadership structure of the firm influences firm financial performance has received a lot of attention in the corporate governance literature. The association between the CEO-Chairman duality and financial performance is usually dealt with through two opposing theories (i.e., agency theory and stewardship theory) in corporate governance studies.

The theory of agency argues that a dual appointment of the CEO and board chairperson or CEO-duality may lead to excessive power concentration in the hands of one person who is both CEO and chairperson of the board (Jensen, 1993). If the same person holds both the CEO and board chairperson positions in the same firm, this may affect firm financial performance negatively because CEO-duality may increase agency conflicts by reducing the level of board independence in the firm. Accordingly, this view supports separation of the CEO and chairman roles, i.e., the firms opting for CEO non-duality structure is likely to have better financial performance compared to those relying upon CEO duality structure (Jensen and Meckling, 1976; Fama and Jensen, 1983; Eisenhardt, 1989; Jensen, 1993; Yermack, 1996). However, contrary to the theory of agency, stewardship theorists argue that the managers who are in charge of governing the firm are intrinsically 
dependable people and effective stewards of the firm assets (Donaldson and Davis, 1991; Davis et al., 1997). Besides, managers (insiders) have more strategic information regarding the firm compared to both independent and outside members of the board. Therefore, if the CEO heads the board, the benefits of powerful leadership and unity of command that duality does engender may contribute to improving the firm's financial performance, i.e., the fact that the CEO and the chairperson of the board are the same people (joint leadership structure) may help improve financial performance, as predicted by the theory of stewardship (Donaldson and Davis, 1991; Ramdani and Witteloostuijn, 2010).

In this study, following the study of Ramdani and Witteloostuijn (2010), we also investigate whether the size of board of directors moderates the duality-performance linkage. The negative impact of Chairperson-CEO duality is supported by theory of agency, while its positive performance effect is defended by the advocates of stewardship theory. Therefore, based on these opposite views, two potential interaction impacts with the size of the board of directors may arise. More specifically, the interactions of CEO duality and board size are likely to be negative or positive.

The 2000-2001 banking crisis experienced in Turkey and the latest financial crisis have revealed how important corporate governance for the banking and financial sector is. Thus, we focus on banking sector to test duality-performance linkage. More clearly, our primary focus for this study is to examine both the impact of CEO duality and the moderating impact of board size on the association between CEO-Chairman duality and financial performance of commercial banks in Turkey. The existing studies in Turkey mostly focus on industrial firms and do not consider the endogeneity of board characteristics and financial variables. Until now, there has been no remarkable paper investigating the moderating influence of the size of the board of directors on duality-performance linkage for Turkey. As a result, our study makes two contributions to the existing literature. First, we take in consideration the problems caused by endogeneity of bank-level variables and board characteristics variables employing system GMM estimator. Second, we investigate the significance of an interaction variable of CEO-duality and board size to understand whether board size moderates the duality-performance association. Estimation results from dynamic panel regression analysis suggest a statistically significant positive association between Turkish banks' CEO duality structure and their financial performance. Additionally, we provide the first evidence of a negative moderating influence of size of board of directors on the positive relation between CEO-Chairman duality and financial performance in Turkish banking sector.

The next section reviews the related literature on duality-performance relation. Model specification, methodology and dataset employed are presented in Section 2. Section 3 presents the dataset on Turkish commercial banks. Section 4 presents the empirical findings and finally, Section 5 concludes.

\section{LITERATURE REVIEW}

Tian and Lau (2001), employing the dataset of 113 Chinese shareholding firms for two years (i.e. 1996 and 1997), analyze the relation between leadership structure and board composition and financial performance. Estimation results show that the influence of CEO-Chairman duality on accounting performance measured as return on assets (ROA) and return on equity (ROE) is positive and statistically significant for both 1996 and 1997.

Kula (2005), using a sample of 386 small and non-listed firms in Turkey, reports that the separation of chairman and CEO positions (i.e., CEO non-duality) has significant positive influence on performance of firm.

Yan Lam and Kam Lee (2008) investigate empirically the association of CEO duality with performance of firm by analyzing a sample of 128 listed firms in Hong Kong in 2003. Their results for full firm sample show that the duality-performance relationship is not significant in both ROA and ROE regression. When their sample is divided into two subgroups as familycontrolled and the non-family firms, the results show that duality significantly enhances the non-family firms' ROA and ROE, whereas this variable causes performance of family controlled firms to diminish.

Kaymak and Bektas (2008) explore the relation of bank board characteristics (CEO duality, board independence, board size, and board tenure) with performance of bank using data for 27 Turkish deposit banks during the period of 2001-2004. Their findings from cross sectional regressions imply that there exists a negative and significant relation between duality and return on assets (ROA) in accordance with agency theory.

Belkhir (2009), investigating the relationship between governance variables such as board size, independence, ownership and CEO characteristics and performance in a sample of 174 U.S. bank (119 bank holding companies-BHC and 55 savingsand-loan holding companies-SLHC) between the years 1995-2002, finds that the impact of CEO-chair duality on performance, as measured by ROA and Tobin's $Q$, is positive and statistically significant in the sub-sample of SLHC.

Based on a sample of 183 firms registered at Istanbul Stock Exchange in Turkey, Aygün and iç (2010) examine how CEOduality influence firm financial performance measured by ROA, ROE, and Tobin's Q value for 2006-2007 years. They report that CEO-duality is negatively and statistically significantly related to firm financial performance. 
Ramdani and Witteloostuijn (2010) analyze empirically how independent directors and CEO duality affect firm financial performance for 313 listed firms from four different East Asian countries (i.e., Thailand, Indonesia, South Korea, and Malaysia) for the period of 2001-2002. The results of quantile regression uncover a negative moderating influence of board size on the positive association between CEO duality and ROA.

Using a sample of 236 US public deposit banks and data over 2005-2008 period, Grove et al. (2011) investigate whether corporate governance explain bank performance. Their results indicate that CEO duality is negatively and significantly associated with bank performance proxied by ROA in the pre-global crisis period (2006 and 2007) but no significant relation in the crisis period (2008)

The relationship between the CEO duality and stock market performance measure (i.e. Tobin's Q) for 199 firms in Sri Lanka between the years 2006-2010 is examined by Hewa Wellalage and Locke (2011). The empirical findings from dynamic panel data estimator indicate that Chairman-CEO duality is positively and significantly related to multinational company subsidiaries' Tobin's $Q$ but it is not significant for local public companies' Tobin's $Q$.

The association between CEO non-duality and performance of 51 Turkish listed firms between the years 1998-2007 is tested by Ersoy et al. (2011). Their regression results show that market-based performance of firms with CEO non-duality structure is better than that of firms having CEO duality structure.

Using a sample consisting of 928 bank-year observations of Turkish deposit banks for the 1988-2009 period, De Jonghe et al. (2012) analyze how internal and external governance mechanisms determine efficiency of banks. As one of internal governance mechanism variables CEO non-duality is found to affect risk/return efficiency of commercial banks positively. In another words, banks which has separation of CEO and chairman positions tend to have higher risk/return efficiency.

Using dynamic panel data estimation technique (system GMM), Veprauskaite and Adams (2013) explore whether powerful chief executives affects the performance of 468 publicly listed UK firms between the years 2003-2008. The results of their analysis reveal that CEO-chairman duality, CEO-ownership, and CEO-tenure are negatively associated with performance of firm.

Employing a sample of 50 largest deposit banks which operate in Chinese banking industry during 2003-2010, Liang et al. (2013) study the relationship between board characteristics (duality structure, bank size and functioning of the board) and bank performance. After their sample is divided into two subsamples of low capitalized and well capitalized banks, taking into account the median capital of banks, they find that influence of duality on bank performance is significantly negative in the sub-sample of well capitalized banks. Besides, the authors re-classify banks as small and large deposit banks based on their total assets. The results from large banks sub-sample reveal that duality is negatively correlated with bank performance.

Using a sample of 204 Turkish listed firms between the years 2009-2010, Doğan et al. (2013) analyze the influence of CEOduality on performance of firms. Based on empirical results, the authors conclude that there is a negative and significant link between duality variable and financial performance measured by accounting and stock market performance measures, i.e., ROA, ROE, and Tobin's Q.

Ammari et al. (2014) explore the linkage board structure and firm performance for 40 French firms over the period of 20022009 using dynamic panel data analysis. Their results from system GMM estimator indicate that duality is negatively correlated with ROE and Tobin's $Q$, while it is positively correlated with market-to-book ratio and ROA.

Nguyen et al., (2014), analyzing empirically the relationship between governance structures and financial performance measured by Tobin's Q during 2008-2011 period through dynamic panel data estimation technique (two-step system GMM), report that COE duality is found to be significantly and positively correlated with market based performance for Singaporean firms.

The association between outside directors and financial performance for a sample of 42 Tunisian firms during 2004-2010 is investigated by Kouki and Guizani (2015). Based on OLS regression analysis, the authors report that leadership structure (i.e. CEO duality) is negatively related to return on assets (ROA). Besides, leadership structure weakens the impact of outside directors on financial performance.

Moscu (2015) studies the relationship between CEO duality and accounting performance measure for a sample of 55 listed Romanian firms during the period 2010-2013. The findings from panel data regression analysis indicate that there is positive and significant linkage between Chairman-CEO duality and return on assets.

Using data of selected 24 banks from Gulf Cooperation Council (GCC) countries in 2012, Naushad and Malik (2015) test the relationships between corporate governance variables and performance of bank. Their results indicate that for both Tobin's $\mathrm{Q}$ and ROA, there is a positive moderating impact of CEO-Chairman duality on board size-performance relationships. 
Employing panel data for 145 Indian non-financial listed firms between the years 2008-2012, Shrivastav and Kalsie (2016) study CEO duality-financial performance linkage by using panel data estimation methods. They use both stock market and accounting performance measures, i.e., Tobin's $Q$ and ROE. The results of their analysis imply that CEO duality structure is negatively and significantly associated with ROE, while it is not found to have a statistically significant influence on Tobin's Q.

Based on a sample of 950 US firms during 1997-2011, Duru et al. (2016) investigate how CEO duality influences operating performance indicators using both static and dynamic panel estimation methods. The results from dynamic panel estimation methods suggest that CEO duality is negatively related to operating performance (represented by ROE, ROA, and ROS). However, it seems that negative effect of CEO duality weakens as board independence increases, i.e. there is a positive moderating influence of the proportion of independent directors on the negative relationship between CEO duality and operating performance measures.

\section{DATA AND METHODOLOGY}

\subsection{Model Specification and Methodology}

The following econometric model which is similar to that of Kaymak and Bektas (2008), Ramdani and Witteloostuijn (2010), and Duru et al. (2016) is specified to explore the impact of duality on profitability of commercial banks in Turkey:

$$
\begin{aligned}
\text { ROAA }_{i t} & =c+\gamma \text { ROAA }_{i t-1}+\alpha_{1} \text { DUALITY }_{i t}+\alpha_{2} \operatorname{Ln}(B S)_{i t}+\alpha_{3}\left[\text { DUALITY }_{i t} \times \operatorname{Ln}(B S)_{i t}\right]+\beta_{1} \text { NIM }_{i t}+\beta_{2} \text { LTA }_{i t} \\
& +\beta_{3} \text { PLLTA }_{i t}+\beta_{4} \operatorname{Ln}(\text { TA })_{i t}+\beta_{5} \text { ETA }_{i t}+\lambda_{\mathrm{t}}+\mu_{\mathrm{i}}+\varepsilon_{i t}
\end{aligned}
$$

In this specification i goes from bank 1 to bank 30 and t takes the values of the years from 2007 to 2013. $R 0 A A_{i t}$ is return on average assets and indicates the financial performance of bank $i$ in period $t ; c$ is the constant term; ROAA $A_{i t-1}$ is the financial performance of bank $i$ in period t-1; DUALITY ${ }_{i t}$ is duality and $\operatorname{Ln}(B S)_{i t}$ is the natural logarithm of board size; DUALITY Dit $\times$ $\operatorname{Ln}(B S)_{i t}$ represents an interaction term between DUALITY and $\operatorname{Ln}(B S)$. We use this interaction variable to study the moderating impact of the size of board of directors on the association between CEO-duality and bank financial performance. DUALITY $_{\text {it }}$ and $\operatorname{Ln}(\mathrm{BS})_{\text {it }}$ are transformed, i.e., former is measured by the mean-centered CEO-Chairman duality and latter is measured by the mean-centered log of board size to reduce potential multicollinearity between original board variables and the interaction variable, as recommended by Duru et al. (2016). $\lambda_{\mathrm{t}}$ and $\mu_{\mathrm{i}}$ are time dummies and bank-specific, timeinvariant effects that are unobserved;, respectively and $\varepsilon_{i t}$ is a classical error term of our model. $\gamma, \alpha$ and $\beta$ are coefficients to be estimated. Five other control variables specified in the above model are defined in Table 1.

In the presence of unknown bank fixed effects as well as the lagged one period of performance variable as one of the explanatory variables in regression equation (1), pooled OLS estimator will be biased upwards and inconsistent due to the fact that there is correlation between $\mathrm{ROAA}_{\mathrm{it}-1}$, the lagged one period of performance variable, and $\mu_{\mathrm{i}}$, unknown bank fixed effects. Since the pooled OLS estimator does not take into account unknown individual effects in the regression equation (1), individual heterogeneity which is not included in the regression equation can emerge in the estimated coefficients. To get rid of the unknown individual effects from each observation, the standard method is to employ fixedeffects estimator (FE). The FE estimator wipes out these effects by transforming variables in Equation (1). Since the FE transformation is based on deviations from individual means, it creates a non-negligible correlation between the new lagged one period of profitability variable and the new disturbance term even if it is assumed that the disturbance terms are not serially uncorrelated. Therefore, the FE estimator will be biased downwards and inconsistent and it does not solve the endogeneity problem stemming from simultaneity in the regression model. Both the pooled OLS and the FE estimator are highly likely to be affected by the problem of endogeneity. If this is the case, the results obtained from these estimators are no longer unbiased and consistent (Nickell, 1981; Hsiao, 2003; Baltagi, 2005; Greene, 2003). The problem of endogeneity which arises when the explanatory variables are associated with the disturbance terms in a regression model is able to be solved by using the dynamic GMM estimation technique. In dynamic panel models framework, Bond (2002), Arellano and Bover (1995) and Blundell and Bond (1998) point out that the system GMM estimator performs better than the first-differenced GMM estimator due to the fact that the latter can suffer from a weak instruments problem. Therefore, they propose the system GMM estimator instead of the first-differenced GMM estimator. The system GMM estimator can efficiently control for all forms of potential endogeneity, such as unobserved heterogeneity, simultaneity and reverse causality by taking into account lagged and differenced values of endogenous explanatory variables as their respective instruments, as discussed in Bond (2002), Arellano and Bover (1995), and Blundell and Bond (1998). Specifically, the dynamic system GMM estimator combines two regression equations: the first one is a first-differenced regression equation which employs lagged values of all variables as instruments and the other one is the regression equation in level which uses their lagged first-differenced values as instruments. System GMM estimator's consistency depends on two specification tests: namely, Hansen test for the validity of instrumental variables and second-order autocorrelation test AR(2) for the firstdifferenced errors. The null hypothesis for Hansen test is that the chosen instruments are valid (i.e., uncorrelated with the error terms). Whereas, the null hypothesis for $\operatorname{AR}(2)$ is that there is no auto-correlation in first-differenced errors. As seen 
from Table 4, both diagnostic tests are satisfied for two regression models. Finally, the results of System GMM are estimated using Windmeijer's (2005) finite sample correction to mitigate the problem of finite sample bias (Roodman, 2009).

\subsection{Dataset}

In our study an unbalanced panel data is constructed for 30 commercial banks that operate in Turkish banking industry. Bank-level data are compiled using the web page of the Banks Association of Turkey. Whereas, detailed information on board variables such as CEO duality and board size are hand-collected from the annual reports of each of commercial banks during 2007-2013. The detailed definitions of dependent, independent and control variables included in the performance equation are presented in Table 1.

Table 1: Definition of Variables

\begin{tabular}{|c|c|c|}
\hline Variables & Abbreviation & Definition \\
\hline \multicolumn{3}{|c|}{ Panel A: Dependent variable } \\
\hline Performance & ROAA & Return on average assets. \\
\hline \multicolumn{3}{|c|}{ Panel B: Independent variable } \\
\hline Duality & DUAL & $\begin{array}{l}\text { A dummy variable that takes a value of } 1 \text { if the general manager is also chairman of } \\
\text { the board, and } 0 \text { otherwise. }\end{array}$ \\
\hline \multicolumn{3}{|c|}{ Panel C: Control variables } \\
\hline Lagged performance & L.ROAA & The one year lagged performance. \\
\hline Board size & $\operatorname{Ln}(B S)$ & The natural logarithm of the total number of members on the board \\
\hline Net interest margin & NIM & Interest revenue less interest expenses divided by total assets \\
\hline Liquid assets & LTA & The ratio of liquid assets to total assets. \\
\hline Bank risk & PLLTA & The ratio of provision for loan losses to total assets. \\
\hline Bank size & $\operatorname{Ln}(T A)$ & Natural logarithm of total assets. \\
\hline Bank capital & ETA & The ratio of total equity to the total assets. \\
\hline Year dummies & YEAR & Seven year dummies for each of the seven years from 2007 to 2013 . \\
\hline
\end{tabular}

\section{RESEARCH RESULTS AND DISCUSSIONS}

\subsection{Descriptive Statistics}

The summary statistics of dependent, independent and control variables are given in Table 2. The mean (median) of ROAA in Turkish banks is $0.019(0.017)$. While the maximum value of this ratio is 0.077 and the minimum value is -0.035 . The mean (median) value of duality (DUAL) is 0.059 (0). It seems that the mean of this variable is lower than those reported by Belkhir (2009) for U.S. banks, Liang et al., (2013) for Chinese banks, Boussaada and Karmani (2015) for the Middle East and North African banks, El-Chaarani (2014) for Lebanese banks and Belhaj and Mateus (2016) for European banks. This shows that only a small proportion of our sample banks have the dual position for general manager and the board chairman. Finally, when we look at the statistics of control variables, the mean (median) of board size (BS) of our sample banks is around 8 (9). The mean (median) net interest margin (NIM), is 0.052 (0.046). The mean (median) liquid assets (LTA), is 0.441 (0.350). The mean (median) bank risk (PLLTA) is 0.010 (0.007). Finally, the mean (median) bank size Ln(TA) and bank capital (ETA) in the sample are $3.710(3.650)$ and $0.195(0.128)$, respectively.

Table 2: Descriptive Statistics

\begin{tabular}{llllll}
\hline Variable & Mean & Median & Max. & Min. & Std. Dev. \\
\hline ROAA & 0.019 & 0.017 & 0.077 & -0.035 & 0.016 \\
DUAL & 0.059 & 0 & 1 & 0 & 0.236 \\
BS & 8.015 & 9 & 14 & 3 & 2.379 \\
NIM & 0.052 & 0.046 & 0.266 & 0.009 & 0.035 \\
LTA & 0.441 & 0.350 & 0.998 & 0.086 & 0.248 \\
PLLTA & 0.010 & 0.007 & 0.048 & 0 & 0.008 \\
Ln(TA) & 3.710 & 3.650 & 5.244 & 1.633 & 0.973 \\
ETA & 0.195 & 0.128 & 0.857 & 0.039 & 0.180 \\
\hline
\end{tabular}

Notes: The sample is an unbalanced panel covering 204 bank-years over the period of 2007-2013. BS represents total number of members on the board. A list of variable definitions is given in Table 1.

\subsection{Pairwise Correlations}

The results of Pearson's correlation analysis are reported in Table 3. Because of the fact that introducing the interaction term (DUAL $\times \operatorname{Ln}(B S))$ to the regression equation normally leads to high correlation between board variables (i.e., DUAL and $\operatorname{Ln}(B S))$ and interaction term, both DUAL and $\operatorname{Ln}(B S)$ are mean-centered, as mentioned above. The variable ROAA is 
positively and significantly correlated with past ROAA, NIM, and ETA. The correlation coefficient between ROAA and the interaction term is negative and significant at $5 \%$ level. This finding is important because the relation between DUAL and $\operatorname{Ln}(B S)$ may cause financial performance to decline. The correlation coefficients between board variables and ROAA are not statistically significant. Similarly, the same holds true for other control variables. When examined the correlation coefficients, it can be said that there is no severe multicollinearity problem in our regression equation, implying that the assumption of independence between the variables is not violated for the analysis. Additionally, our study also performs a variance inflation factor (VIF) analysis to make sure that there is no problem of multicollinearity. According to the VIF values calculated for each of regressors, the highest (lowest) VIF value is 3.19 (1.23). This indicates that all of the regressors have VIF values of less than 10 and they can be employed in the same regression equation (Guajarati, 2004). Besides, the correlation coefficient between ROAA in the current period and L.ROAA in the previous period is 0.57 . This justifies using the dynamic panel data estimators.

Table 3: Correlation Matrix

\begin{tabular}{|c|c|c|c|c|c|c|c|c|c|c|c|}
\hline & (1) & (2) & (3) & (4) & (5) & (6) & (7) & (8) & (9) & (10) & VIFs \\
\hline (1) & 1 & & & & & & & & & & \\
\hline (2) & $.57^{\mathrm{a}}$ & 1 & & & & & & & & & 1.23 \\
\hline (3) & .09 & .08 & 1 & & & & & & & & 1.71 \\
\hline (4) & -.10 & -.10 & $-.25^{\mathrm{a}}$ & 1 & & & & & & & 1.99 \\
\hline (5) & $-.15^{b}$ & -.14 & $-.69^{\mathrm{a}}$ & $.18^{\mathrm{a}}$ & 1 & & & & & & 1.79 \\
\hline (6) & $.20^{a}$ & -.02 & .04 & $-.25^{\mathrm{a}}$ & .02 & 1 & & & & & 1.80 \\
\hline (7) & .09 & .12 & .13 & $-.57^{\mathrm{a}}$ & -.08 & $.27^{\mathrm{a}}$ & 1 & & & & 2.28 \\
\hline (8) & -.07 & -.02 & .04 & $.20^{\mathrm{a}}$ & .002 & $.27^{a}$ & $-.27^{\mathrm{a}}$ & 1 & & & 1.43 \\
\hline (9) & .06 & .08 & $-.21^{\mathrm{a}}$ & $.61^{a}$ & $.25^{\mathrm{a}}$ & $-.30^{\mathrm{a}}$ & $-.62^{\mathrm{a}}$ & $.15^{\mathrm{b}}$ & 1 & & 3.07 \\
\hline (10) & $.20^{\mathrm{a}}$ & $.15^{\mathrm{b}}$ & .13 & $-.36^{\mathrm{a}}$ & $-.16^{b}$ & $.56^{\mathrm{a}}$ & $.62^{\mathrm{a}}$ & -.10 & $-.67^{\mathrm{a}}$ & 1 & 3.19 \\
\hline
\end{tabular}

Notes: (1) ROAA; (2) L.ROAA; (3) mean-centered DUAL; (4) mean-centered Ln(BS); (5) DUAL× Ln(BS); (6) NIM; (7) LTA; (8) PLLTA; (9) Ln(TA), and (10) ETA. ${ }^{\mathrm{a}}$ and ${ }^{\mathrm{b}}$ indicate statistically significant at $1 \%$ and $5 \%$ level. A list of variable definitions is given in Table 1.

\subsection{Empirical Results}

The System GMM parameter estimates as well as all relevant diagnostic test statistics are reported in Table 4. We first estimate our regression specification without the interaction term of CEO-duality and board size and report the results in column 1 of Table 4. A statistically significant positive relationship is found between CEO-duality and the bank financial performance (ROAA). This means the CEO-Chairman duality structure is beneficial for commercial banks in Turkey. Our empirical result regarding duality is supported by stewardship theory but not agency theory.

This result on the leadership structure reported in Table 4 is consistent with the results of previous studies focused on the corporate governance-financial performance relationship (e.g., Tian and Lau, 2001; Belkhir, 2009; Ramdani and Witteloostuijn, 2010; Ammari et al., 2014; Moscu, 2015), but is also in contradiction to those of most of the earlier research (e.g., Rechner and Dalton, 1991; Kaymak and Bektas, 2008; Grove et al., 2011; Veprauskaite and Adams, 2013; Liang et al., 2013; Doğan et al., 2013; Kouki and Guizani, 2015 and Duru et al., 2016; among others). With regard to the size of boards $(\operatorname{Ln}(B S))$, there is a negative relation between $\operatorname{Ln}(B S)$ and ROAA but this relation is not statistically significant i.e., the size of boards has no significant influence on ROAA.

Regarding other control variables, ROAA is positively and significantly associated with past financial performance (L.ROAA), showing that past performance is a significant determinant of current performance. The impact of net interest margin (NIM) on bank performance is positive and significant. The positive impact of NIM on ROAA implies that as NIM rises, ROAA increases. Our results imply that there is not a significant association between liquidity ratio (LTA) and ROAA, i.e., bank financial performance is not influenced by liquidity level of commercial banks. Bank risk measured by the ratio of provision for loan losses to total assets (PLLTA) is significantly and negatively correlated with ROAA, suggesting that higher bank risk leads to lower ROAA. Finally, the estimated coefficients on bank size $(\operatorname{Ln}(T A))$ and bank capital (ETA) are positive but not statistically significant, i.e., they are not significant determinants of bank financial performance.

We next re-estimate our baseline equation by adding interaction term to understand how board size moderates the relationship between CEO duality and financial performance. Our empirical findings are reported in column 2 of Table 4 . All of the coefficient estimates except for that of CEO-duality variable are same in terms of sign and significance. The estimated coefficient on CEO-duality variable is now negative but insignificant, showing that CEO-duality has no significant effect on bank performance. When we examine the results of the regression model with interaction term, the estimated coefficient on interaction variable between CEO duality and size of the boards is found to be negative and statistically significant. Thus, this study's finding reveals a negative moderating influence of size of board of directors on the positive association between Chairman-CEO duality and financial performance of commercial banks. These results may indicate that as the number of 
members of the board rises, the positive influence of CEO-duality decreases. This finding is in line with the earlier finding of Ramdani and Witteloostuijn (2010). However, our result contradicts those of Naushad and Malik (2015) and Duru et al. (2016).

Table 4: The Association between Duality and Bank Financial Performance

\begin{tabular}{|c|c|c|c|c|}
\hline & \multicolumn{4}{|c|}{ Dependent variable: ROAA } \\
\hline & \multicolumn{2}{|c|}{ Model-I } & \multicolumn{2}{|c|}{ Model-II } \\
\hline & Coef. & SES & Coef. & SES \\
\hline L.ROAA & $0.315^{* *}$ & 0.111 & $0.302 * *$ & 0.107 \\
\hline DUAL & $0.022 * * *$ & 0.007 & -0.001 & 0.006 \\
\hline $\operatorname{Ln}(B S)$ & -0.041 & 0.051 & -0.034 & 0.038 \\
\hline DUALX $\times \operatorname{Ln}(B S)$ & & & $-0.070 * *$ & 0.031 \\
\hline NIM & $0.150 * *$ & 0.067 & $0.142^{* *}$ & 0.058 \\
\hline LTA & -0.010 & 0.013 & -0.009 & 0.011 \\
\hline PLLTA & $-0.524 * * *$ & 0.158 & $-0.552 * * *$ & 0.156 \\
\hline $\operatorname{Ln}(T A)$ & 0.0004 & 0.010 & 0.002 & 0.010 \\
\hline ETA & 0.010 & 0.027 & 0.009 & 0.025 \\
\hline Intercept & 0.010 & 0.045 & 0.004 & 0.042 \\
\hline Bank fixed-effects & Yes & & Yes & \\
\hline Year dummies & Yes & & Yes & \\
\hline \multicolumn{5}{|l|}{ Diagnostic tests } \\
\hline F-test statistics & $10.53 * * *$ & & $75.40 * * *$ & \\
\hline Hansen test statistics & 16.50 & & 18.48 & \\
\hline $\mathrm{AR}(2)$ test statistics & 0.94 & & 0.88 & \\
\hline Number of instruments & 27 & & 30 & \\
\hline Observations & 168 & & 168 & \\
\hline Banks in sample & 30 & & 30 & \\
\hline
\end{tabular}

Notes: Dependent variable is ROAA. See Table 1 for rest of the variables' definitions. PLLTA is treated as predetermined variable, while all other variables are treated as endogenous variables except for year dummies. For model 1, lag 2 and lag 3 of the levels of corporate governance variables (DUAL and Ln(BS)), lag 2 of NIM, LTA, Ln(TA) and ETA, lag 1 and lag 2 of PLLTA, lag 2, lag 3, and lag 4 of bank financial performance are employed as GMM-type instruments in the transformed equations. Meanwhile, first difference of predetermined variable and first lagged differences of endogenous variables are employed as GMM-type instruments in the original equations. For model 2, lag 2 and lag 3 of the levels of corporate governance variables (DUAL and $\operatorname{Ln}(B S)$, and [DUALx $\operatorname{Ln}(B S)]$ ), lag 2 of NIM, LTA, Ln(TA) and ETA, lag 1 and lag 2 of PLLTA, lag 2, lag 3, and lag 4 of bank financial performance are used as GMM-type instruments in the transformed equations, while first difference of predetermined variable and first lagged differences of endogenous variables are instrumented in the original equations based on GMM procedure The GMM instrument matrix is collapsed to avoid instrument proliferation, As suggested by Roodman (2009). Year and bank dummies are included but not reported. ${ }^{* * *} p<0.01, * * p<0.05$ ve $*<0.1$

\section{CONCLUSION}

In this study, we focus on Turkish banking sector to test duality-performance linkage by employing an unbalanced panel of 204 bank-years observations from a total 30 commercial banks between the years 2007-2013. For our study, the return on average assets (ROAA) is employed to measure Turkish banks' financial performance. Both the influence of CEO-Chairman duality on banks' financial performance and the moderating role of board size on the linkage between the CEO-Chairman duality and financial performance of Turkish commercial banks are empirically analyzed by considering the problems caused by endogeneity of bank-level variables and board characteristics variables through dynamic panel data estimation method (i.e., system GMM). The empirical findings presented in this study suggest that in the case of Turkish commercial banks, the CEO-Chairman duality as a governance mechanism is positively and significantly associated with financial performance. In other words, strong leadership structure of bank board enhances financial performance. This finding is also supported by the advocates of stewardship theory. With regards to the interaction of the CEO-Chairman duality and the size of the board of directors, we find empirical evidence of a negative moderating influence of size of board of directors on the positive association between the CEO-Chairman duality and financial performance, i.e., a statistically significant negative impact of the CEO-Chairman duality on bank financial performance is significantly and positively moderated by the size of board of directors, suggesting that as the number of members of the board rises, the positive influence of CEO-Chairman duality decreases. This could be explained by the view that a larger bank board causes the problems regarding coordination, control, and communication in decision-making process to increase. Thus, this could result in a reduction of the benefits of the CEO-Chairman duality. However, our study does not take into account the influences of other board characteristics variables (i.e., independent directors, foreign directors, female directors, politically-connected directors, etc.) and their interactions with Turkish banks' board size on the financial performance of commercial banks. An analysis of how these 
board variables might affect performance of Turkish banks can be a potential area for future studies. Besides, we do not control the influence of ownership structures of commercial banks. For the future studies the performance influence of CEO-Chairman duality could be analyzed in terms of ownership structure.

\section{REFERENCES}

Ammari, A. B. B., Kadria, M., \& Ellouze, A. 2014. "Board Structure and Firm Performance: Evidence from French Firms Listed in SBF 120", International Journal of Economics and Financial Issues, 4(3), pp. 580-590.

Arellano, M., \& Bover, O. 1995. "Another Look at the Instrumental Variable Estimation of Error-Components Model", Journal of Econometrics, 68, pp. 29-51.

Aygün, M. ve İç, S. 2010. “Genel Müdürün Aynı Zamanda Yönetim Kurulu Üyesi Olması Firma Performansını Etkiler mi?”, Muhasebe ve Finansman Dergisi, Sayı: 47, s. 192-201.

Belhaj, S., \& Mateus, C. 2016. "Corporate Governance Impact on Bank Performance Evidence From Europe", Corporate Ownership \& Control, 13(4), pp. 583-597.

Baltagi, B. H. 2005. Econometric Analysis of Panel Data, 3rd edition, John Wiley\&Sons Ltd., West Sussex, England.

Belkhir, M. 2009. "Board of Directors' Size and Performance in the Banking Industry", International Journal of Managerial Finance, 5(2), pp. 201-221.

Blundell, R., \& Bond, S. 1998. "Initial Conditions and Moment Restrictions in Dynamic Panel Data Models", Journal of Econometrics, 87(1), pp. $115-143$.

Bond, S. R. 2002. “Dynamic Panel Data Models: A Guide to Micro Data Methods and Practice”, Portuguese economic journal, 1(2), pp. 141162.

Boussaada, R., \& Karmani, M. 2015. “Did Board of Directors Have an Impact on MENA Bank Performance?”, International Journal of Economics and Finance, 7(4), pp. 46-56.

Davis, J. H., Schoorman, F. D., \& Donaldson, L. 1997. "Toward a Stewardship Theory of Management", Academy of Management Review, 22(1), pp. 20-47.

De Jonghe, O., Disli, M., \& Schoors, K. 2012. “Corporate Governance, Opaque Bank Activities, and Risk/Return Efficiency: Pre-and Post-Crisis Evidence from Turkey", Journal of Financial Services Research, 41(1-2), pp. 51-80.

Doğan, M., Elitas, B. L., Agca, V. \& Ögel, S. 2013. "The Impact of CEO Duality on Firm Performance: Evidence from Turkey", International Journal of Business and Social Science, 4(2), pp. 149-155.

Donaldson, L. \& Davis, J. H. 1991. "Stewardship Theory or Agency Theory: CEO Governance and Shareholder Returns", Australian Journal of Management, 16(1), pp. 49-64.

Duru, A., lyengar, R. J., \& Zampelli, E. M. 2016. "The Dynamic Relationship between CEO Duality and Firm Performance: the Moderating Role of Board Independence", Journal of Business Research, 69(10), pp. 4269-4277.

Eisenhardt, K. M. 1989. “Agency theory: An Assessment and Review”, Academy of Management Review, 14(1), pp. 57-74.

El-Chaarani, H. 2014. "The Impact of Corporate Governance on the Performance of Lebanese Banks", the International Journal of Business and Finance Research, 8(5), pp. 35-46.

Elsayed, K. 2010. "A Multi-theory Perspective of Board Leadership Structure: What Does the Egyptian Corporate Governance Context Tell Us?, British Journal of Management, 21(1), pp. 80-99.

Ersoy, E., Bayrakdaroğlu, A. ve Şamiloğlu F. 2011. "Türkiye'de Kurumsal Yönetim ve Firma Performansı (Tobin-Q ve Anormal Getiri) Arasındaki İlişkinin Analizi", Finans Politik \& Ekonomik Yorumlar, 48(554), s. 71-83.

Fama, E. F., \& Jensen, M. C. 1983. "Separation of Ownership and Control”, the journal of law and Economics, 26(2), pp. 301-325.

Greene, W. H. (2003), Econometric Analysis (5th ed.). Singapore: Pearson Education Inc.

Grove, H., Patelli, L., Victoravich, L. M., \& Xu, P. T. 2011. “Corporate Governance and Performance in the Wake of the Financial Crisis: Evidence from US Commercial Banks", Corporate Governance: An International Review, 19(5), pp. 418-436.

Gujarati, D.N., (2004). Basic Econometrics (4th Ed.), The McGraw-Hill Companies, Avenue of the Americas, New York.

Hewa Wellalage, N., \& Locke, S. 2011. "Does CEO Duality is Really Matter? Evidence from an Emerging Market”, Corporate Ownership \& Control, 8(4), pp. 112-122.

Hsiao, C., (2003). Analysis of Panel Data. Cambridge University Press. 
Jensen, M. C. 1993. "The Modern Industrial Revolution, Exit, and the Failure of Internal Control Systems", the Journal of Finance, 48(3), pp. 831-880.

Jensen, M. C., \& Meckling, W. H. 1976. "Theory of the Firm: Managerial Behavior, Agency Costs and Ownership Structure", Journal of financial Economics, 3(4), pp. 305-360.

Kaymak, T., \& Bektas, E. 2008. "East Meets West? Board Characteristics in an Emerging Market: Evidence from Turkish Banks", Corporate Governance, 16(6), pp. 550-561.

Kouki, M., \& Guizani, M. 2015. “Outside Directors and Firm Performance: The Moderating Effects of Ownership and Board Leadership Structure", International Business Research, 8(6), pp. 104-116.

Kula, V. 2005. "The Impact of the Roles, Structure and Process of Boards on Firm Performance: evidence from Turkey", Corporate Governance, 13(2), pp. 165-176.

Liang, Q., Xu, P., \& Jiraporn, P. 2013. “Board Characteristics and Chinese Bank Performance”, Journal of Banking \& Finance, 37(8), pp. 29532968.

Montgomery, C. A., \& Kaufman, R. 2003. "The Board's Missing Link", Harvard Business Review, 81(3), pp. 86-93.

Moscu, R. G. 2015. "Study on Correlation between CEO Duality And Corporate Performance of Companies Listed on the Bucharest Stock Exchange", Journal of Social and Economic Statistics, 4(1), pp. 47-53.

Nickell, S. 1981. "Biases in Dynamic Models with Fixed Effects", Econometrica, 49, pp. 1417-1426.

Nahar Abdullah, S. 2004. "Board Composition, CEO Duality and Performance among Malaysian Listed Companies", Corporate Governance: The International Journal of Business in Society, 4(4), pp. 47-61.

Naushad, M., \& Malik, S. A. 2015. "Corporate Governance and Bank Performance: A Study of Selected Banks in GCC Region", Asian Social Science, 11(9), pp. 226-234.

Nguyen, T., Locke, S., \& Reddy, K. 2014. "A Dynamic Estimation of Governance Structures and Financial Performance for Singaporean Companies", Economic Modelling, 40, p. 1-11.

Nicholson, G. J., \& Kiel, G. C. 2007. "Can Directors Impact Performance? A Case-Based Test of Three Theories of Corporate Governance", Corporate Governance: An International Review, 15(4), pp. 585-608.

Ramdani, D., \& Witteloostuijn, A. V. 2010. "The Impact of Board Independence and CEO Duality on Firm Performance: A Quantile Regression Analysis for Indonesia, Malaysia, South Korea and Thailand", British Journal of Management, 21(3), pp. $607-627$.

Rechner, P. L., \& Dalton, D. R. 1991. "CEO Duality and Organizational Performance: A Longitudinal Analysis”, Strategic Management Journal, 12(2), pp. 155-160.

Roodman, D. 2009. "How to do xtabond2: An Introduction to Difference and System GMM in Stata” The Stata Journal, 9(1), pp. 86-136.

Shrivastav, S. M., \& Kalsie, A. 2016. "The Relationship Between CEO Duality and Firm Performance: An Analysis Using Panel Data Approach", IUP Journal of Corporate Governance, 15(2), pp.37-58.

Strebel, P. 2004. "The Case for Contingent Governance", MIT Sloan Management Review, 45(2), pp. 59-66.

Tian, J. J., \& Lau, C. M. 2001. "Board Composition, Leadership Structure and Performance in Chinese Shareholding Companies", Asia Pacific Journal of Management, 18(2), pp. 245-263.

Veprauskaitè, E., \& Adams, M. 2013. "Do Powerful Chief Executives Influence the Financial Performance of UK Firms?", The British Accounting Review, 45(3), pp. 229-241.

Windmeijer, F. 2005. "A finite Sample Correction for the Variance of Linear Efficient Two-Step GMM Estimators", Journal of Econometrics, 126(1), pp. 25-51.

Yan Lam, T., \& Kam Lee, S. 2008. "CEO Duality and Firm Performance: Evidence from Hong Kong”, Corporate Governance: The International Journal of Business in Society, 8(3), pp. 299-316.

Yermack, D. 1996. "Higher Market Valuation of Companies with a Small Board of Directors", Journal of Financial Economics, 40, pp. 185211. 